Meta

Journal des traducteurs

Translators' Journal

\title{
Sense and Nonsense: The Literary Significance of Semantic Contradictions and Tautology in Okot p'Bitek's Song of Lawino
}

\section{Ogo A. Ofuani}

Volume 35, numéro 4, décembre 1990

URI : https://id.erudit.org/iderudit/003758ar

DOI : https://doi.org/10.7202/003758ar

Aller au sommaire du numéro

Éditeur(s)

Les Presses de l'Université de Montréal

ISSN

0026-0452 (imprimé)

1492-1421 (numérique)

Découvrir la revue

Citer cet article

Ofuani, O. A. (1990). Sense and Nonsense: The Literary Significance of Semantic Contradictions and Tautology in Okot p'Bitek's Song of Lawino. Meta, 35(4),

701-709. https://doi.org/10.7202/003758ar
Résumé de l'article

A knowledge of the collocational principles governing the cooccurrence of words aids the linguistic analyses of eccentric poetic usages such as oxymoron, paradox, and tuatology. These forms can be more formally linguistically analysed and insights gained complement the literary critic's efforts. This paper shows how these semantically deviant constructions contribute to "meaning" in Okot p'Bitek's Song of Lawino. Lawino exploited them for satire. Tautology is vacuous, empty, meaningless; but she used it to communicate her disgust and dissatisfaction at her husband's unsociable behaviour. Her use of oxymoron and paradox is linked to her tendency to exaggerate; but these exaggerations are to shock her erring husband to realization. He had shriked his marital and parental responsabilities and needed to be reminded. Their literary significance hinge on their situational meaningfulness. The critic must develop the ability to understand, explain and interpret such usages; and thus make literary sense of semantic nonsense. 


\title{
SENSE AND NONSENSE: THE LITERARY SIGNIFICANCE OF SEMANTIC CONTRADICTIONS AND TAUTOLOGY IN OKOT P'BITEK'S SONG OF LAWINO
}

OGO A. OFUANI

University of Benin, Benin City, Nigeria

\begin{abstract}
A knowledge of the collocational principles governing the cooccurrence of words aids the linguistic analyses of eccentric poetic usages such as oxymoron, paradox, and tuatology. These forms can be more formally linguistically analysed and insights gained complement the literary critic's efforts. This paper shows how these semantically deviant constructions contribute to "meaning" in Okot p'Bitek's Song of Lawino. Lawino exploited them for satire. Tautology is vacuous, empty, meaningless; but she used it to communicate her disgust and dissatisfaction at her husband's unsociable behaviour. Her use of oxymoron and paradox is linked to her tendency to exaggerate; but these exaggerations are to shock her erring husband to realization. He had shriked his marital and parental responsabilities and needed to be reminded. Their literary significance hinge on their situational meaningfulness. The critic must develop the ability to understand, explain and interpret such usages; and thus make literary sense of semantic nonsense.
\end{abstract}

\section{I}

Poets have always fascinated their readers and critics in the way they hold sway over our emotions through their use of obvious eccentric linguistic patterns. Such eccentricities have often been vaguely dismissed as "poetic licence," a losse term for all poetic fabrications of language ranging from puns, oxymoron, paradox, hyperbole, litotes, to metaphors, similes, synedoche and metonymy. These features are not devoid of linguistic explanations once their source texts are regarded as discourse involving some literary cmmunication. As linguistic elements, they can be given semantic analyses because they, in some ways, help the texts to "mean."

The meaning of a sentence is not always just a sum total of the lexical features of its components. There are meaning relationships that hold over and above the individual meanings of the word and morphemes in the sentence. They involve the words entering into certain paradigmatic and syntagmatic relations - into what are generally called collocations ${ }^{1}$. There are many constraints on what lexical items can combine with what others ${ }^{2}$. In literary discourse, the knowledge of collocational principles governing the cooccurrence of words aids us in the linguistic analysis of most of the instances of eccentric poetic usage. Those meaning relations that interest us in this paper are contradiction aud tautology. Ordinarily, the two terms have negative connotations, and imply "nonsense." They are analysed here because of the fascinating and intricate manner 
they have helped in making literary sense out of their apparent semantic nonsense in Okot p'Bitek's Song of Lawino.

\section{II}

The term contradiction, as used here, subsumes p'Bitek's poetic exploitation of the two poetic licences of oxymoron and paradox because both involve a certain degree of linguistic absurdity in which what is said conveys self-conflicting information. Generally, a contradiction is a situation in which something is explicitly said "to be both $\mathrm{x}$ and not $x "$ at the same time (Traugott and Pratt: 205). Oxymoron and paradox are lumped together here because they are two types of linguistic absurdity which entail irreconciliable elements of meaning or reference. Although they are separately discussed, often the comments used for one have application for the other.

Oxymoron, according to Geoffrey Leech, involves the yoking together of two expressions which are semantically incompatible, so that in combination they have no conceivable literal reference to reality (A Linguistic Guide to English Poetry: 132). The poetic use of this kind of absurdity in Song of Lawino is illustrated in the passages below. The way in which we arrive at an interpretation of oxymoron can be seen if we place passage (1) in its context:

(1) And as you walk along the pathway

On both sides

The Obiya grasses are flowering

And the pollok blossoms

And the wild white lilies

Are shouting silently

To the bees and butterflies! (pp. 56-57)

In (1), Lawino describes the fauna and flora of her village, particularly the fragrance of the flowers. Passage (1) is a complex sentence in which multiple coordination takes place with the aid of "And" (lines 3, 4, and 7). Line 1-2 provide a premise, giving us a context in which the person addressed as "you" notices the situation in lines 3-7. The lines (3-7) can be divided into two parts to illustrate the deviant structure of oxymoron in this text. The first part is made up of line 3 which is normal because whait it describes is not contrary to expectation. "The obiya grasses are flowering" is a simple clause of the S ("The obiya grasses") and V ("are flowering") structure ${ }^{3}$. No collocational restrictions are broken in this clause. Both literally (and therefore logically) and semantically, the line is normal and does not defy ordinary interpretation. Its sense is very straightforward. So syntactically and semantically, there is no discord; it is meaningful and acceptable.

The opposite is the case in the second part of text (1) - lines 4-7. They make up one complex clause in which two Subjects (Agents) are coordinated: "the pollok blossoms" and "the wild white lilies." The Subject (Agent) in the first part contrasts with the Subjects (Agents) in the second because there is a discord in the relationship between the V component ("are shouting") and the A component ("silently") in line 6. We can explai the abnormality in lines 4-7 at two main levels. First, is that they involve the poetic use of the device of personification in which NON-HUMAN objects are given HUMAN attributes 4 . We realise that "pollok blossoms" and "wild white lilies" cannot perform the action of the verb "shout" but are given such attributes all the same. The second and significant one for us here is the contradiction in line 6 . given that we allow the personification, and semantically (though illogically) allow "blossoms" and "lilies" to 
"shout," we cannot logically expect a hout to be "silent." So the expression in line 6 ("shouting silently") is contradictory because there is a collocational disagreement (at the syntagmatic level) between the placement of the present progressive verb phrase "are shouting" in the context of the adverb of manner, "silently." They contradict because they are at polar ends of one contrasting semantic feature, LOUDNESS: "shouting" (+LOUDNESS/NOISE) and "silently" (-LOUDNESS / NOISE).

But as a poetic discourse text, the use of the exymoron in (1) is explicable. Lawino is perhaps exaggerating but wants to emphasize that the flowers are so colourful and fragrant that they tend to "shout" at the bees and butterflies in order to attract them. She also quickly realizes that as non-human objects, these plants are incapable of speech. She therefore adds the qualifying adverb "silently." Hence the contradiction.

A second example (2) arises as Lawino describes her fears about the effect of books on anyone who stays long enough in Ocol's library (which she sees as a "dark forest" to get infested:

(2) The deadly vengeance ghosts

Of the writers

Will capture your head,

And like my husband

You will become

A walking corpse. (p. 204)

We will ignore Lawino's ignorance about books in (2) and proceed to the oxymoron in line 6 ("a walking corpse"). The last two lines, "You will become / A walking corpse," are contradictory. The sentence has an SVC structure but there is a semantic disagreement between the constituents of the Complement component. "A walking corpse" is a noun phrase in which the adjective "walking" modifies the noun "corpse" as Head. But they do not readily collocate. This discord however seems more logical than semantic. Just as in (1), we wonder at the possibility of a corpse "walking." The participle (-ing) adjective "walking" derived from the verb "walk" has the semantic features + ANIMATE, + LIFE and + MOBILITY (DYNAMIC). On the other hand, "corpse" has + ANIMATE?, - LIFE, and - MOBILITY (STATIC). So the active verb "walk" does not collocate with the static noun "corpse." The two items conflict on at least two levels (life and motion). A corpse has no life and cannot move unless in supernatural situations such as the psychic/magical reanimation of corpses (in this context called "zombies") 5 . Though Lawino does not specifically refer to such animation, there is a link which lends her usage its significance. Zombies ("walking corpses") are supposed to be controlled by their animators; they have no volition and her husband Ocol's present behaviour in a situation in which his education (Lawino suggests) has overtaken his good sense. Thus, to Lawino's rural thinking, Ocol's misbehaviour can only be given this kind of spiritual explanation (other clues to this interpretation of psychic possession in the passage include the "vengeance ghost," and its "capture" of the head of the object, "you").

The explanation of the absurdity in (2) applies to that of (3) where Lawino talks about the effect of electrocution, and in (4) where she describes the effect of ill health on an under-nourished baby:

(3) If you touch it

It runs through you

And cuts the heart string

As they cut the umbilical cord,

And you stand there, dead,

A standing corpse! (p. 68) 
(4) When your child is weak and listless,

When his energy fails him,

When he withdraws from the fight

For life, and gives up quickly,

It seems his head has been captured,

And he is only a crawling corpse. (p. 162)

The similarities between text (2), on one hand, and texts (3) and (4), on the other, are easy to discern. The same level of ignorance about electricity (the "it" of lines 1 and 2 of text 3 ) and death (in 4) is exhibited. But semantically relevant are the expressions "a standing corpse" in (3) and "a crawling corpse" in (4). The explanation given about the absurdity of "a walking corpse" in (2) is made even more vivid in line 5 of (3) where we are told that the object (Patient - "you") is already "dead." This implies the inability to "stand" (+ VERTICAL POSITION) for a "corpse" which will be lying prone (and so VERTICAL or + HORIZONTAL POSITION). In (4), "crawling" (+ MOTION, + LIFE) contrasts with "corpse" (- MOTION, - LIFE).

Another dimension in Lawino's use of oxymoron is shown in passage (5). Love is a theme of universal and profound poetic significance which lends itself to semantic contradictions. In (5), Lawino describes the effect of a satisfying sexual relationship:

(5) Then the young cobs Will scream

And shed tears of sweet pains! (p. 171)

Although excising these lines from their context deprives the reader of many clues to interpretation, it is an interesting exercise if we interpret them as another instance of oxymoron and then analyse the result.

In text (5) above, we have drawn attention to "tears of sweet pains" because the juxtaposition of "tears" + "sweet" + "pains" is rather puzzling. But these words become more meaningful if taken in the context of the whole text $(5$, above). In line 1 , there is the reference to "young cobs" which "scream" (line 2). "Cobs," taken literally, are objects of food (maize cobs). They are incapable of screaming, and the contradiction we find in (1) between "blossoms" and "lilies" and their action of "shouting" applies here as "cobs" cannot perform a human act ("scream"). So there is personification here. If we explain off that the cobs can figuratively "scream," and so by extension "shed tears," we find it difficult to explain the juxtaposition of "tears" and the qualifying "sweet pains."

The whole of (5) is a compound sentence in which the Subject ("young cobs") takes the complex verb phrase "will scream/And shed" and the object ("tears of sweet pains"). The object is a noun phrase of HQ structure6. "Tears" constitute the Head of this noun phrase and "of sweet pains" its elaborative qualifier (or postmodifier). The contradiction is in the completive element of this $Q$ (prepositional phrase) structure: "sweet pains." Shedding tears could be consequent screaming, and both ("scream" and "tears") connote and collocate with "pains" as all are signs of negative feelings or sensations - a response to certain unsavoury stimulus. On the other hand, "sweet" does not seem the most logical modifier for "pains" since their semantic feature contrast: "sweet" (+ PLEASURE) vs "pains" (- PLEASURE). Their juxtaposition therefore causes a contradiction.

In Lawino's usage, however, the expression "tears of sweet pains" seems to testify to hymanity's ability to experience pleasure mingled with pain, a type of apprent absurdity which we can interpret as a mixture of sweetness and sorrow which reminds us of the everyday expression "tears of joy." In the larger context, the passage is uttered in one of Lawino's lightheart moments when she can afford to be humorously flippant. 
Passages (1) to (5) analysed above make it easy to dismiss Lawino's apparent predilection for the use of oxymoron as exaggerations, in agreement with the suggestion that there is an association between sex and the preference for hyperbolic statements, that "hyperbole seems predominantly a characteristic of female speech" (Leech: A Linguistic Guide..., 170). While not disagreeing with this suggestion, intertextual evidence in his other songs, particularly Song of Prisoner, shows that p'Bitek did not restrict such usages to female characters?.

\section{III}

As a parallel to oxymoron, paradox involves a statement which is absurd, because it is self-evidently false. Thus, much the same comments that applied to oxymoron above apply to paradox. Texts (6), (7), and (8) provide a basis for discussion:

(6) Time has become My husband's master, It is my husband's husband (p. 95)

(7) He borrows the clothes he wears And the ideas in his head And his actions and behaviour Are to please somebody else.

Like a woman trying to please her husband! My husband has become a woman! (p. 207)

(8) Then your child becomes

Sickly and thin

His knees become

Soft like porridge

He will become pregnant (p. 100)

In text (6), Lawino complains about her husband's attitude towards time. Here, to bolster her point, she exaggerates. Lines 1-2 ("Time has become/My husband's master") can be allowed, even given an easy literal interpretation if we agree with Lawino that Ocol has allowed time to dominate him. Line 3 is meant to emphasize this domination, but in saying so Lawino employs a paradoxical statement ("It is my husband's husband"). A paraphrase of line 3 reveals where the paradox lies. In actual fact, Lawino should have said "My husband is Time's wife" in which case two antonyms, "husband" and "wife" are equated. This equation of antonyms is perhaps the simplest and boldest form of paradox. The contradiction in (6) hinges on the sense that "husband's husband" is collocationally incompatible: "husand" (+ MARRIED MALE) needs a contrasting item like "wife" (- MARRIED FEMALE), for the expression to be semantically acceptable. The genitive modifier "husband's should not under such situation take its own semantic equivalent as Head.

But then we can provide a semantico-cultural explanation for Lawino's use. Ali Mazrui explains that in Acoliland where the poem takes its context, the word "husband" has all the connotations of "maleness," strength, protection of the household, valour, foresight, determination, wisdom, etc. (40-49). These are features expected of and in a husband. But part of Lawino's complex protest in her Song is that Ocol has shirked his role as husband, and so she suggests that these qualities are absent in Ocol. Thus in section 7 of this Song, Lawino decries Ocol's pedantic insistence on the use of the clock for the control of every situation. Her own lack of understanding of the working of a clock is basic to the conflict between them. To her, Ocol's behaviours enumerated in the 
section are absurd. She, therefore, attributes his misdeeds to this excessive dependence on time. In allowing something else dominate him, he is abdicating his role as husband to time. Hence "husband's husband" - he becomes subordinate to it, and so, in Lawino's thinking, becomes time's wife.

In (7), the same situation is being re-created, though here Lawino is being more specific and her insult more incisive. In (6), "husband's husband" is not as direct as the blunt statement in line 6 of text (7) - "My husband has become a woman." The semantic explanations for (6) apply for (7) but we do not need a paraphrase for the abnormality to sink home. As in (6), "husband" is MALE while "woman" is FEMALE. To a reasonable extent, the same degree of equation of antonyms we find in (6) applies to (7), and is also extended to text (8).

Passage (8) talks about the effect of malnutrition on a baby whose mother does not practise birth control and so has an over-sized family. Lines 1 and 5 are underlined to show the significant clues to the paradox. If we relate "child" to "pregnant," we notice an absurdity in implying what is biologically impossible. A "child" has the main distinguishing features of being - ADULT HUMAN, while "Pregnancy" is a state or process of biological development only possible in adulthood and has the semantic features of + ADULT HUMAN PROCESS / STATE. But the absurdity in (7) is increased by the specification of the child's sex. A child cannot become pregnant because of age; though at maturity, if it is female, it can. But the absurdity is stretched because we are told to take the impossible as possible. Antonyms are again equated. "He" is MALE, and "pregnant" is a FEMALE process. We can, therefore, only give a figurative interpretation to passage (7). It can only be explained as a reference to the effect of the dreadful malnutrition disease, kwashiokor, which distends an affected child's stomach. Lawino usage is metaphorical and the ground for the comparison is clear.

\section{IV}

Another routine licence which p'Bitek exploits is tautology. A "tautology" is a statement which is vacuous because self-evidently true. It is thus a case of redundancy in poetry. As semantic forms, tautologies become problematic because they provide no new information: they simply say " $\mathrm{x}$ is $\mathrm{x}$ " (Traugott and Pratt: 206). Tautologies are not false or absurd the way contradictions are. In fact, tautologies by definition can never be false: $\mathrm{x}$ is indeed always $\mathrm{x}$. While contradiction violates the organisation of sense in a sentence, tautology seems rather to violate pragmatic rules requiring that utterances include information which is new and relevant. That tautology is pragmatic rather than a semantic kind of deviance per se is suggested by the fact that there are contexts in which tautology is not deviant. As Elizabeth Traugott and Mary Louise Pratt illustrate, the statement "A dog is an animal" is tautological, but is practically well-formed as an answer to the question "what is a dog?" (206). Usually they have a conventional meaning which involves foregrounding the concrete reality of what is referred to as against an unrealistic or over-idealized conception of it.

Tautology is a device of limited usefulness in literature. p'Bitek, however, provides a textual example of its appropriate and deliberate use in Song of Lawino where it has been used for ironic emphasis:

(9) But oh! Ocol

You are my master and husband,

You are the father of these children

You are a man,

You are you! (p. 205) 
In section 12 of Song of Lawino, entitled "My husband's house is a dark forest of books," Lawino laments the negative influence of Western education in alienating Ocol (and other young men) from his Acoli culture. Before passage (9), Lawino's utterances were directly invective, as she scolds Ocol. But in (9), her tone changes. The change is itself syntactic as it is marked by the contrastive coordinator "But." We do not also miss the parallel nature of lines 2-5 where "You are..." is repeated, but in each occasion a different complement noun phrase is provided, all of them referring back to "You" in Subject position. Lines 2-4 of (9) may sound tautological because they do not seem to convey any new information that we do not already know. But then, there are degrees in the repetition of information in these lines. Where lines $2-4$ have the structure $X=Y$, line 5 has $X=X$. We notice immediately that lines 2 and 3 are reiterations of Lawino's recognition of Ocol's position in his family: as her "master and husband" and as "father" of their children. These lines are not literally (and even literarily) redundant if placed in the context of Ocol's reported rejection of Lawino and her children. These lines are not literally (and even literarily) redundant if placed in the context of Ocol's reported rejection of Lawino and her children. They act as a reminder to Ocol about his responsibilities. Hence Lawino does not use any other verb form but the equative copula $B E$ which takes the responsibilities (husband, father, man) as given.

Line 4 is vacuous to the extent that it re-states the obvious: for if Ocol is not man - in the literal sense of being MALE, he would not be "husband" (line 2) and "father" (line 3). Lines 2, 3, and 4 thus constitute a lexical set in their complements ("husband" + "father" + "man") because these items have a cultural connotation reiterating Ocol's fulfilment of his expected manly duties of being a husband to his wife, a father to his children, and these, therefore, making him really a "man." To fulfil these duties, he exhibits those qualities expected of the male sex (hence the emphatic "You are a man!")

We cannot give this type of interpretation to line 5 ("You are you!) which cognitively means $-X$ is $X-$. But line 5 too can be taken literally. If Ocol has done all that Lawino expects of him (in lines 2-4), then line 5 is also emphatic. If he is the "son of a Chief," "the son of a Bull," and a "Prince" - all the praise-names which Lawino showers on him - and if he behaves true to type, and so is - being himself - (to borrow another popular tautology), through exhibiting those qualities, then Lawino can emphatically applaud and re-state the obvious ("You are you!") The exclamation is a clue to the excitement in Lawino's approval. That is "you" (the Chief, Prince, etc.) behaving like "you" (the father, husband, man). Hence the equation, and thence the tautology.

Lawino's statement in text (9) above, if given the type of pragmatic interpretation above, may not be completely tautological, though it is so close to it as to reveal no information worth having. The cryptic statement "You are you!" matches the popular tautology in the remarks "I know what I know," "War is war," and "Boys will be boys." But Lawino's tautology in (9) is ironical: the cloak of idiocy in re-stating the obvious hides her true thoughts and feeling. In the context in which she tells Ocol "You are aman!" she is being ironical by letting him know that he is shirking his responsibilities. What textually precedes and what follows (9) show the oppsoite of the apparent praise in (9). It is after (9), for instance, that Lawino utters the contradictory statement in text (7) above, when she says "My husband has become a woman" (207). It is also in the same section that she calls on her clausmen to "Come/Let us all mourn the death of my husband" (207). In the same section too, Lawino laments that the "manhood" of their educated Acoli "young men" was finished "In the classrooms,/Their testicles/Were smashed/With large books" (208). So the apparent vacuity of (9) becomes significant if it is related to what precedes and what follows it, textually. These contextual clues make 
Lawino's utterances ironic. She is thus only reminding Ocol about what he should be or ought to be: a father and husband, a man.

The lack of cognitive content in lines 4 and 5 of (9) does not necessarily go with a lack of significance. Instead, they provide us a clue about Lawino's character and frame of mind. In re-stating the obvious, she is being diplomatic in her language by deferring to Ocol. Her central message is however understood!

\section{V}

As one of Africa's most prominent poets, Okot p'Bitek's works, particularly Song of Lawino, have attracted considerable scholarly attention from critics who have in the process provided useful contributions to our understanding of p'Bitek's themes, images, historical and biographical background, and traditional poetic devices. Lamentably, little effort seemed spared in providing stylistic (linguistic) analyses of most of these devices. The attempt so far in this paper has, therefore, been to show that some of the more traditional forms, like oxymoron and paradox, can be more formally linguistically analysed, and that insights consequently gained will complement the literary critic's efforts. The approach has been in two directions. First, the analysis of Lawino's exploitation of obvious tautological language for satirical purposes shows that the stylistic significance of a featur edoes not necessarily depend on its recurrence in a text. The only single instance of tautology in Song of Lawino has been shown to be prominent because it contains shades of meaning which could be missed out if overlooked. It has shown that no single aspect of the language of a literary text is irrelevant, and that at times significant messages ares conveyed by even the most simplistic features. ${ }^{8}$ In a semantic sense, then, tautology is vacuous, empty and meaningless; but the analysis above confirms that, like most other situations in everyday experience in which there is a necessity for redefinition, this feature has helped Lawino to communicate her disgust and dissatisfaction at her husband's unsociable behaviour. The semantically empty utterance in text (9) above is thus literarily significant because it is situationally meaningful.

The second direction is provided by the analyses of the two poetic devices of oxymoron and paradox that are, unlike tautology, clearly semantically deviant for being contradictory forms. Our analysis has shown how we can find reason in apparent absurdity by not only explaining the sources of semantic contradictions in texts (1) to (8) but also to suggest their significance. As with most such absurd poetic usages, the only rational explanation for this kind of phenomenon is to suggest that poets use them because they have "the mystic feeling that reality to some extent lies beyond the literal, commonplace views of life as systematized in ordinary language. Therefore, the poet to reach it, must violate the normal rules of language" (Leech, A Linguistic Guide...: 143). Such violations are not inexplicable, as we have shown, and often the reader has to develop, as part of his communicative/literary competence, the ability to understand, explain, and interpret such usages.

Generally, our aim has been to show not only how literary sense is mad eout of apparent semantic nonsense, but to offer a procedure for making explicable those intuitions we may have long had about a literary work like Song of Lawino. Our perceptions may be clarified and made credible through the use of such a stylistic approach. 
NOTES

1. The idea of collocations emanated from the neo-Firthian British linguists. It involves the claim that lexical entries belong to sets which have certain "ranges," that is, tolerable extensions; a considerable degree of emphasis is laid on how cooccurrence patterns can be extended. These collocational patterns are discussed by J. R. Firth; M. A. K. Halliday, Angus McIntosh, and P. Strevens: The Linguistic Sciences and Language Teaching; Halliday: "Lexis as a Linguistic Level," 148-163; McIntosh: "Patterns and Ranges," 325 337; and $\mathbf{J}$. McH Sinclair, 401-430.

2. Such constraints are called "selectional restrictions" in the terminology of Noam Chomsky's Aspects Transformational Generative Grammar because they govern the selection of lexical items for inserting into underlying structures.

3. In the model of linguistic description used here, after Quirk, Greenbaum, Leech and Svartvik (A Grammar of Contemporary English), English clause structure is SVOCA for Subject, Verb, Object, Complement and Adverbial, respectively.

4. Semantic relationships are explained in terms of plus $(+)$ or minus $(-)$ shared lexical characteristics using the componential analysis method where features are assigned to lexical items to determine the extent of their collocational relationships. See Manfred Bierswich: "Semantics," 164-184.

5. The Chambers Twentieth Century Dictionary defines a Zombie as "a corpse reanimated by sorcery" (1523).

6. In the grammar, the English noun phrase has three main constituents: premodifiers, the Headword, and postmodifiers. But for descriptive ease, Halliday's analysis is adopted, in which the constituents are Modifier (M), Head (H) and Qualifier (Q). The Head is obligatory. See "Categories in the Theory of Grammar," 241-292.

7. The prisoner's song features a male persona who used two instances of hyperbolic contradictions: "There is a colourless rainbow / On the bleak white walls" (12), and "Their infant pregnancies / Are years overdue..." (22).

8. Geoffrey Leech's suggestion that only "foregrounded" elements are stylistically attention-drawing ("This Bread I Break...," 119-128) has been countered by Halliday's "positive prominence" ("Linguistic Function and Literary Style...," 103-140).

\section{BIBLIOGRAPHY}

BIERSWICH, Manfred (1970): "Semantics," New Horizons in Linguistics, Ed. John Lyons, Harmondsworth, Penguin Books, pp. 166-184.

CHOMSKY, N. A. (1965): Aspects of the Theory of Syntax, Cambridge, Mass., M.I.T. Press

FIRTH, J. R. (1957): Papers in Linguistics, 1934-1951, London, Oxford University Press.

HALLIDAY, M. A. K. (1961): "Categories in the Theory of Grammar," Word 17, pp. 241-292.

HALLIDAY, M. A. K. (1966): "Lexis as a Linguistic Level," Memory of J. R. Firth, Ed. C.E. Bazell, J. C. Catford, M. A. K. Halliday and R. H. Robins, London, Longman, pp. 148-163.

HALLIDAY, M. A. K. (1973): "Linguistic Function and Literary Style: An Inquiry into the Language of William Goldings The Inheritors," Explorations in the Functions of Language, London, Amold, pp. 103-140.

HALlIDAY, M. A. K., A. McIntosh, and P. Strevens (1964): The Linguistic Sciences and Language Teaching, London, Longman.

KIRKPATRICK, E. M., ed. (1963): Chambers Twentieth Century Dictionary, New Edition, Edinburgh, Chambers Ltd.

LEECH, Geoffrey N. (1969): A Linguistic Guide to English Poetry, London, Longman.

LEECH, Geoffrey N. (1970): "This Bread I Break: Language and Interpretation," Linguistics and Literary Style, Ed. Donald C. Freeman, New York, Holt, Rinehart and Winston, pp. 119-128.

MAZRUI, Ali A. (1974): "Phallic Symbols in Politics and War: An African Perspective," Journal of African Studies 1, 4, pp. 40-49.

McINTOSH, Angus (1961): "Patterns and Ranges," Language 37, pp. 325-337.

F'BITEK, Okot (1966): Song of Lawino: A Lament, Nairobi, East African Publishing House.

F'BITEK, Okot (1971): Two Songs: Song of Prisoner, Song of Malaya, Nairobi, East African Publishing House.

QUIRK, Randolph, Sidney GREENBAUM, Geoffrey LEECH and Jan SVARTVIK (1972): A Grammar of Contemporary English, Revised, Corrected, London, Longman.

SINCLAIR, J. McH (1966): "Beginning the Study of Lexis," In Memory of J. R. Firth. Ed. C. E. Bazell et al. London, Longman, pp. 401-430.

TRAUGOTT, Elizabeth Closs and Mary Louise PRATT (1980): Linguistics for Students of Literature, New York, Harcout Brace Jovanovich. 